as a trusted friend and adviser of British diplomatists in St. Petersburg, but they will certainly agree that to the end of his life he kept undimmed that courtly charm of manner, warmth of heart, and vivacity of mind which made a most attractive, amiable, and inspiriting personality, clad in a handsome, athletic form, thoroughly English.

A short obituary notice appeared in The Times on 21st February.

41 .

O. W.

\title{
C. Mabel Rickmers
}

The death of Mrs. Rickmers on Christmas Eve, 1939, has left another gap in the small band of English women who towards the end of last century took up the study of Indian languages and literature. Mrs. Rhys Davids and Miss Ridding are still with us, and Mrs. Bode has left scholarly contributions to the Pāli Text Society and to our own Prize Publications Fund.

Mabel Duff was the granddaughter of that pioneer among Scotch missionaries in India, Dr. Alexander Duff, and doubtless inherited his interests in India and the Indian peoples. She studied Sanskrit at Kiel under Dr. Paul Deussen, the eminent Vedānta scholar, and translated into English his Manual of Vedānta Philosophy.

Her best known contribution to Indian Studies is her Chronology of India, Constable, published in 1899, a much wanted and useful book of reference, the compilation of which took patient study and research. She married in 1897 the well-known explorer and mountaineer, Willy Rickmers, living for some years in London, where they had a large circle of friends, before they undertook their first expedition into Central Asia. Starting from Bokhara they made a three weeks' journey on horseback into the wild fastnesses of Turkestān. Some of their adventures were recounted by Mrs. Rickmers in a paper to the Society. 
She accompanied her husband on many expeditions into Central Asia, the Caucasus, and the Balkans, and was an intrepid traveller, ski-runner, and mountaineer. Her sense of humour, added to her courage, carried her through many dangers and difficulties and added much to her accounts of their adventures.

For some years now they have devoted themselves to literary work, alternating with long ski-ing expeditions in the Austrian and Bavarian highlands, their names being well known in the world of Alpine sports.

Mrs. Rickmers had complete command of the German language and has done good work in translating English books on Indian subjects into German and vice versa. She also contributed reviews to the Society's Journal.

She had a good life and a dangerous one, and enjoyed it to the full. Her loss will be much felt by her many friends. 43.

C. Frazer.

\section{George Eumorfopoulos}

Wherever Chinese art is valued, the name of George Eumorfopoulos has long been honoured as that of a great collector and discerning critic. Contributing to this fame were his numerous loans to exhibitions and gifts to museums, the publication of his collection catalogue, and finally the purchase of his collection by the nation. But perhaps he became even more widely known through personal contact with those countless visitors from all countries whom he welcomed in his home at Clandon and, since 1922, on the Chelsea Embankment. Among devotees of Oriental culture who have come to England, scarcely one can have left without seeking this privilege, always so readily granted. With equal hospitality the house and collection were thrown open to the uninitiated, many of whom must have been moved by their host's enthusiasm to start on the discovery of a new world.

He had a catholic taste; many Persian and mediæval 